\title{
Aransemen Lagu "Tanah Airku” Karya Ibu Sud Oleh Joko Suprayitno (Tinjauan Variasi Melodi)
}

\author{
Muhammad Muchlis Faturrozi \\ Program Studi Seni Musik Fakultas Bahasa dan Seni Universitas Negeri Surabaya \\ Email: muchlis789@yahoo.co.id
}

\begin{abstract}
The song Arrangement "Tanah Airku" by Ibu Sud by Joko Suprayitno entitled "variation on tanah airku" is an arrangement with a unique form, which is a variation of the theme. Forms of variations of this theme use a lot of variations of the melody so that the authors are interested in researching about the variation of the melody technique. This study discusses the structure of the song "Tanah Airku" by Ibu Sud first and then the variations of the melody used in the arrangement are discussed. In parsing this melodic variation, the theory used is the theory of arrangements, motifs, song form, and melody variations. In analyzing song structure and melody variations, the research approach used is a qualitative research approach. In this method, the research subject is a full score of "variation on tanah airku" by Joko Suprayitno with the object of research being melody variation. The data source used was from the full score of "variation on tanah airku" by Joko Suprayitno and the data collection techniques used were through interviews with informants (in this case Joko Suprayitno) and relationships. The analysis results obtained are the structure of the song "Tanah Airku" consisting of 3 phrases and 6 motifs. The arrangement of arrangements made by Joko Suprayitno starts from the introduction, themes, variations of I-VII, cadenza, and finally the finale. From this structure, variations in melodies that occur in the main melody are melodic and fake variations through non-chordal, ornaments and sequences. Then the variations used when the main melody include, fillers (melody fillers, tails, contents), counter melodies, obbligato, cliches, and fillers such as obbligato. Melodic variations used by Joko Suprayitno are melodic and fake variations via nonchordal and filler.
\end{abstract}

Keywords: Arrangement, Melodic Variation

\begin{abstract}
Abstrak: Aransemen lagu "Tanah Airku" karya Ibu Sud oleh Joko Suprayitno yang diberi judul "variation on tanah airku" merupakan aransemen dengan keunikan bentuknya yaitu variasi tema. Bentuk variasi tema ini banyak menggunakan variasi melodi sehingga penulis tertarik meneliti tentang teknik variasi melodinya. Penelitian ini membahas struktur lagu "Tanah Airku" karya Ibu Sud terlebih dahulu kemudian barulah dibahas variasi melodi yang digunakan dalam aransemen tersebut. Dalam mengurai variasi melodi ini, teori yang digunakan adalah teori aransemen, motif, bentuk lagu, dan variasi melodi. Dalam menganalisa struktur lagu dan variasi melodi, pendekatan penelitian yang digunakan adalah pendekatan penelitian kualitatif. Dalam metode tersebut subjek penelitiannya adalah full score "variation on tanah airku" oleh Joko Suprayitno dengan objek utamanya yaitu variasi melodi. Sumber data yang digunakan adalah dari full score "variation on tanah airku" oleh Joko Suprayitno dan teknik pengumpulan data yang digunakan adalah melalui wawancara dengan narasumber (yang dalam hal ini Joko Suprayitno) dan dokumentasi. Hasil analisa yang didapat adalah struktur lagu "Tanah Airku" terdiri dari 3 frase dan 6 motif. Alur aransemen yang dibuat oleh Joko Suprayitno ini dimulai dari bagian introduction, theme, variasi I-VII, cadenza, dan yang terakhir finale. Dari struktur tersebut, variasi melodi yang terjadi pada melodi utama adalah melodic variation and fake via non-chordal, ornament dan sekuensi. Sedangkan variasi yang digunakan diluar melodi utama antara lain, filler (melodic filler, tail, fill in), counter melody, obbligato, cliché, dan filler like obbligato. Variasi melodi yang banyak digunakan Joko Suprayitno adalah melodic variation and fake via non-chordal dan filler.
\end{abstract}

Kata Kunci: Aransemen, Variasi Melodi

\section{PENDAHULUAN}

Indonesia merupakan negara yang kaya akan lagu nasionalnya. Lagu nasional yang fungsinya sejak dahulu digunakan sebagai pembangkit semangat kebangsaan dan pemersatu bangsa. Hal ini dapat dilihat dari lagu-lagu seperti Halo-Halo Bandung, Satu Nusa Satu Bangsa, Hari Merdeka,
Garuda Pancasila, Bagimu Negeri, Dari Sabang Sampai Merauke dan banyak lagi. Bahkan lagu kebangsaan Indonesia Raya pun yang ditetapkan menjadi lagu kebangsaan Indonesia juga merupakan salah satu lagu nasional yang sejak jauh sebelum kemerdekaan hingga saat ini menjadi lagu pembangkit semangat kebangsaan sekaligus pemersatu bangsa. 
Selain menjadi pembangkit semangat kebangsaan dan persatuan bangsa, beberapa lagu nasional juga menjadi gambaran keindahan dan kebesaran alam Indonesia. Lagu-lagu tersebut seperti Indonesia Pusaka, Rayuan Pulau Kelapa, Nyiur Hijau, Tanah Airku, dan banyak lagi. Judul terakhir yang disebutkan memiliki tema khusus mengenai kerinduan dan cinta terhadap tanah air Indonesia. Karya Saridjah Niung atau yang lebih dikenal dengan nama Ibu Soed itu menceritakan betapa bangga dan cintanya seorang Ibu Soed pada tanah air sehingga selalu rindu pada alam Indonesia.

Ibu Sud dikenal sebagai tokoh musik tiga zaman (Belanda, Jepang, Indonesia). Kariernya di aspek musik malahan sudah dimulai jauh sebelum kemerdekaan Indonesia. Suaranya pertama kali disiarkan dari radio NIROM Jakarta periode 19271928. Setelah menamatkan pendidikan di HKS Bandung, Ibu Soed kemudian menjadi guru musik di HIS Petojo, HIS Jalan Kartini, dan HIS Arjuna yang masih menggunakan Bahasa Belanda (19251941). Beliau prihatin menonton anak-anak Indonesia yang tampak kurang mantap saat itu. Hal ini membuat Ibu Soed berpikir untuk memuaskan mereka dengan bernyanyi lagu ceria. Didorong rasa patriotisnya, Ibu Soed ingin mengajar mereka untuk menyanyi dalam Bahasa Indonesia. Dari sinilah Ibu Soed mulai menciptakan lagu-lagu yang bersifat ceria dan patriotik untuk anak-anak Indonesia.

Dari sekian banyak lagu ciptaan beliau yang sebagian besar diperuntukkan pada anak-anak, terdapat beberapa lagu yang bertemakan patriotisme seperti Berkibarlah Benderaku dan Tanah Airku. Karena tema lagu tentang kecintaan dan kerinduan akan keindahan alam Indonesia, lagu Tanah Airku sendiri sempat menjadi lagu penutup di akhir siaran beberapa televisi seperti Tuban TV (masih rencana), stasiun televisi Family Television, Fajar TV, Parijz van Java TV, SBO TV, TVRI Jawa Timur, CIP TV, Radio KPFM, Kelapa TV (masih rencana), Simpang Lima TV, KSTV, Jujur Jember TV, Buton TV (masih rencana), TV Sumbawa Barat, PonTV, Sakti TV Madiun, Sumedang TV, TVKU Semarang, TV Beruang \& Papua TV. (dikutip dari http://ibusud.koran.web.id/id1/306-199/Ibu-

Sud_112232_ibu-sud-koran.html, pada tanggal 5 Maret 2019 pukul 12:20 WIB).

Dapat dilihat peranan lagu tersebut pada masyarakat yang bukan hanya sebagai lagu patriotik namun sudah menjadi lagu hiburan yang tetap tak kehilangan makna kebangsaannya. Hal ini memungkinkan beberapa orang mulai mengaransemen lagu tersebut. Aransemen sendiri menurut Kamus Musik (Banoe, 2003) merupakan gubahan lagu untuk orkes atau kelompok paduan musik, baik vokal maupun instrumenal. Sedangkan menurut Ensiklopedia Musik Klasik (Syafiq, 2003) aransemen merupakan penyesuaian komposisi musik dengan nomor suara penyanyi atau instrumen lain yang didasarkan pada sebuah komposisi yang telah ada sehingga esensi musiknya tidak berubah.

Dari pengertian diatas, maka dapat ditarik kesimpulan bahwa aransemen merupakan gubahan lagu untuk orkes maupun kelompok musik baik vokal maupun instrumental, yang tidak menghilangkan esensi musik dari lagu aslinya. Teknik aransemen dalam musik dapat mencakup perubahan birama (sukat), perubahan tangga nada (dari tangga nada major ke tangga nada minor, dan sebaliknya), pergerakan harmoni, beat pattern iringan, dan irama melodi.

Arangger (sebutan bagi seorang penulis aransemen) yang cukup terkenal dan kini merupakan arrangger di Jakarta Philharmonic Orchestra (JPO) yaitu Joko Suprayitno. Beliau merupakan salah satu orkestrator andalan dari ISI Yogyakarta. Selain itu, Joko Suprayitno adalah seorang pemain trombone dan juga aktif dalam berbagai kegiatan musik diantaranya, musik klasik, Pop, dan Jazz. Selain itu juga Joko berprofesi sebagai dosen tetap di Institut Seni Indonesia Yogyakarta, Fakultas Seni Pertunjukan, Jurusan Seni Musik sebagai dosen mayor trombone dan ensembel tiup.

Karya aransemen orkestrasi Joko antara lain Hanya PadaMu (2006) lagu karya Lukman Snada, Bila Waktu T'lah Berganti (2006) karya Opick, Rindu Rasul (2006) karya Bimbo/Taufik Ismail, Cahaya Shalawat (2006), Preludium Ibu Pertiwi (2000), Sedih Indonesiaku (2002), Aransemen untuk ensambel tiup Kau dan Liku, Aransemen untuk Solo Biola, serta salah satunya adalah aransemen Tanah Airku karya Ibu Soed. Dari sekian lagu tersebut, aransemen Tanah Airku merupakan salah satu aransemen beliau yang sangat unik karena bentuknya yang merupakan variasi tema.

Sebuah aransemen untuk solo clarinet dan orkestra ini memiliki keunikan, antara lain karena bentuknya adalah variasi tema. Variasi tema adalah sebuah teknik merubah melodi utama suatu lagu. Dalam aplikasinya, variasi tema ini dilakukan dengan mengubah irama melodi, birama (sukat), tangga nada, dan juga pattern dari iringannya. Artinya dalam variasi tema ini secara tidak langsung mengubah kontur dari cantus firmus (melodi utama) lagu tersebut. Jenis aransemen dalam bentuk variasi tema ini jarang ditemui, ditambah lagi dalam bentuk variasi tema ini, cantus firmus (melodi utama) lagunya divariasikan dengan menarik. Mulai dari menyajikan melodi utama dalam beberapa birama 
(sukat) berbeda diawal lagu, lalu perubahan tonalitas (nada dasar) dari major ke minor, dan diakhiri dengan variasi dimana clarinet dan orkestra bersahut-sahutan memainkan beberapa motif lagu tersebut yang divariasi. Oleh karena itu penulis tertarik untuk mengkaji bagaimana teknik variasi melodi pada lagu Tanah Airku karya Ibu Soed yang diaransemen oleh Joko Suprayitno.

\section{METODE}

Penelitian ini menggunakan pendekatan penelitian kualitatif deskriptif karena variable penelitian merupakan objek yang tidak perlu menggunakan pengukuran dan proses statistik. Menurut Moleong (2001:6), data penelitian kualitatif yang dikumpulkan adalah data yang berupa kata-kata, gambar, dan bukan merupakan angka-angka. Penelitian ini bertujuan untuk mendeskripsikan variasi melodi pada aransemen lagu "Tanah Airku" karya Ibu Sud oleh Joko Suprayitno yang akhirnya nanti akan diteliti dimulai dari pemetaan motif dan frase lagu "Tanah Airku" karya Ibu Sud, dilanjutkan alur aransemen lagu "Tanah Airku" gubahan Joko Suprayitno dan kemudian variasi melodi pada aransemen lagu "Tanah Airku" karya Ibu Sud gubahan Joko Suprayitno. Data yang dianalisis adalah full score lagu "Variation on Tanah Airku" karya Joko Suprayitno.

Subjek penelitian ini adalah full score lagu "Variation on Tanah Airku" karya Joko Suprayitno dan objek penelitiannya adalah variasi melodi pada lagu "Variation on Tanah Airku" karya Joko Suprayitno. Sumber data dalam penelitian ini diperoleh dari full score lagu "Variation on Tanah Airku" ditambah dengan wawancara dengan narasumber yaitu Joko Suprayitno untuk kepentingan identifikasi dan verifikasi data yang ada. Teknik pengambilan data dari penelitian ini yaitu dengan metode wawancara dan dokumentasi. Peneliti sendiri menunjuk Joko Suprayitno sebagai narasumber yang sekaligus arranger lagu "Variation on Tanah Airku". Dokumentasi disini berupa full score lagu "Variation on Tanah Airku".

Data penelitian yang diperoleh melalui teknik pengumpulan data yang memiliki bentuk berupa potongan-potongan melodi yang diidentifikasi sebagai bagian dari variasi melodi maupun datadata yang didapat dari hasil wawancara. Setelah melakukan pengambilan data, langkah selanjutnya yang dilakukan peneliti adalah menganalisis.

Dalam suatu penelitian, teknik analisis data merupakan suatu bagian yang penting, sebab dalam bagian inilah suatu data yang terkumpul akan diolah untuk menjadi suatu data yang sinkron dan tersusun secara rapi. Teknik analisis yang digunakan dalam penelitian ini adalah teknik analisis kualitatif. Teknik analisis kualitatif menggunakan proses berfikir induktif sehingga sesuai dengan kebutuhan peneliti dalam menganalisa variasi melodi pada aransemen lagu "Tanah Airku" karya Ibu Sud oleh Joko Suprayitno.

Langkah selanjutnya yang dilakukan oleh peneliti setelah data tersaji secara sistematis dan terperinci adalah menarik kesimpulan dan verifikasi data tersebut. Peneliti mendeskripsikan hasil analisis dan kemudian disimpulkan. Kesimpulan penelitian yang diperoleh tertsebut kemudian dikaji dengan menggunakan teori yang ada. Proses yang dilakukan peneliti adalah wawancara kepada Joko Suprayitno guna mengecek dan membandingkan hasil analisis peneliti dengan Joko Suprayitno selaku arranger lagu "Variation on Tanah Airku".

\section{HASIL DAN PEMBAHASAN}

\section{Struktur Lagu "Tanah Airku” Karya Ibu Sud}

Motif lagu adalah unsur yang terdiri dari sejumlah nada yang dipersatukan dengan suatu gagasan/ide (Prier, 2004:3) sedangkan frase adalah usaha untuk memperlihatkan struktur kalimat dalam sebuah lagu (Prier, 2004:4).

Dalam lagu Tanah Airku karya Ibu Sud tersebut terdapat 6 motif dan 3 frase. Hal ini telah dijabarkan Prier (2004:15) dalam buku Ilmu Bentuk Musik, bahwa lagu Tanah Airku ini di satu pihak nampak segar karena setiap pertanyaan dan jawaban membawa motif baru, dan di pihak lain agak sukar untuk dihafal karena tidak ada pengulangan.

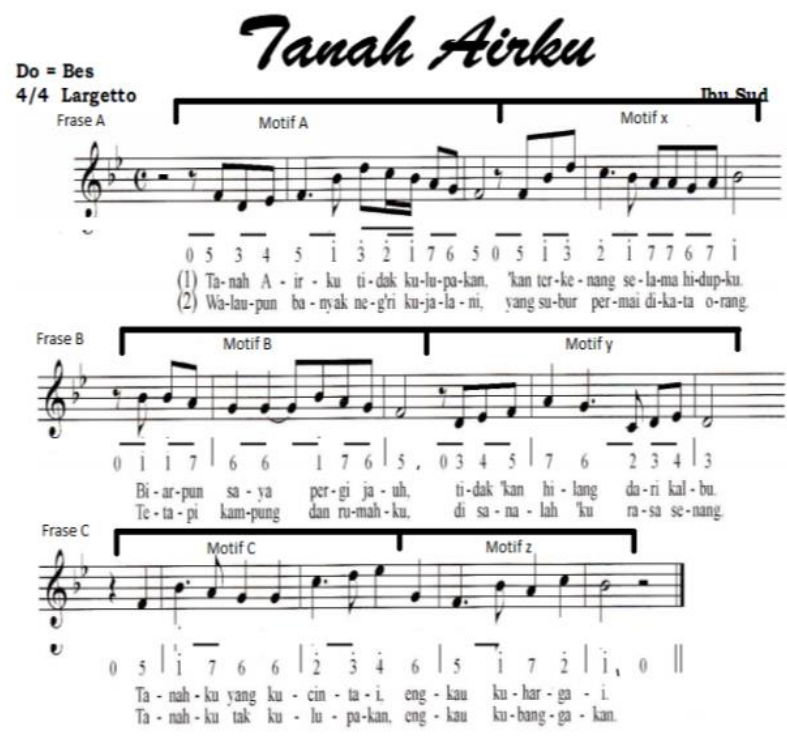
Ibu Sud

Gambar 1. Motif pada lagu "Tanah Airku” karya

Dilihat dari gambar diatas, nampak terdapat 6 motif yang membentuk lagu ini, yaitu motif $\mathrm{A}, \mathrm{x}, \mathrm{B}$, y, C dan z. Motif A merupakan pertanyaan kalimat 
/ frase A sedangkan motif $x$ merupakan jawaban dari kalimat / frase A. Selanjutnya Motif B merupakan pertanyaan dari frase B sedangkan motif y merupakan jawaban dari kalimat atau frase B. Terakhir motif $\mathrm{C}$ merupakan pertanyaan kalimat $\mathrm{C}$ dan motif $\mathrm{z}$ merupakan jawaban dari kalimat $\mathrm{C}$.

\section{Alur Aransemen}

Aransemen lagu "Tanah Airku" karya Ibu Sud oleh Joko Suprayitno terdiri dari 166 birama + okmat 1 ketukan diawal. Tanda birama (sukat) yang digunakan pada aransemen lagu "Tanah Airku" karya Ibu Sud oleh Joko Suprayitno dari awal hingga akhir adalah 4/4.

Aransemen ini dimainkan dibagi menjadi 11 bagian yang terdiri dari bagian introduction, Theme, Variasi I - VII, Cadenza, dan Finale. Dalam setiap bagian tersebut, Joko Suprayitno juga memberikan marking huruf (A, B, C, dan seterusnya) kecuali bagian introduction, sehingga marking dimulai dari bagian theme hingga bagian finale.

Dalam aransemen ini dalam 4 nada dasar yaitu $\mathrm{Bb}$ major, Eb major, $\mathrm{C}$ minor dan $\mathrm{F}$ major. Perubahan tangga nada ini dilakukan dengan menambahkan jembatan yaitu dari Eb major menuju $\mathrm{C}$ minor, dan 2 perpindahan lain diubah dengan menggunakan salah satu bagian aransemen yaitu variasi IV (mengubah dari $\mathrm{Bb}$ major menjadi Eb major) dan cadenza (mengubah dari $\mathrm{C}$ minor menuju $\mathrm{F}$ major). Namun karena cadenza dalam aransemen itu adalah bagian untuk unjuk kemampuan virtuosonya maka pemindahan dari $\mathrm{C}$ minor menuju $\mathrm{F}$ major dilakukan oleh virtuosonya secara bebas.

Dalam aransemen ini terdapat juga beberapa variasi melodi yang terdapat di luar melodi utama di beberapa bagian. Contoh variasi melodi yang terdapat di beberapa bagian akan dijelaskan dibawah ini.

\section{Melodic filler}

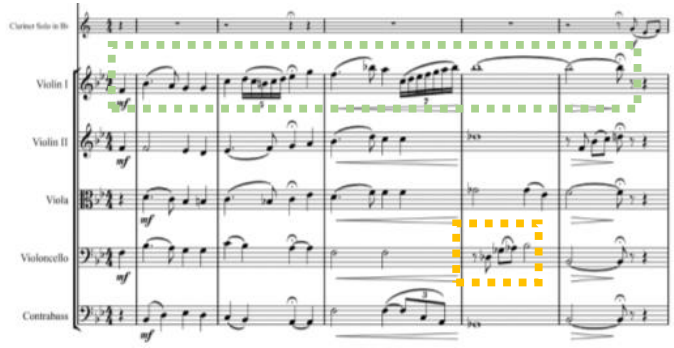

Notasi 1. Melodic Filler pada bagian introduction

Notasi 1 menunjukkan terdapat variasi dead spot filler pada birama 4 bagian introduction yang dimainkan oleh violoncello. Kotak dengan garis berwarna hijau menandai bagian melodi utama sedangkan kotak dengan garis berwarna kuning menandai bagian melodic filler.

Pemberian melodic filler yang pertama ini dilakukan pada ketukan pertama sampai ketukan ketiga pada birama 4 bagian introduction. Melodic filler yang pertama ini terjadi ketika susunan nada Db3 Gb3 Ab3 Bb3 dengan nilai nada 1/8, bergerak pada bagian sisa garis melodi utama yang berjalan pada violin I. Dengan rest $1 / 2$ ketukan pada ketukan pertama, maka susunan nada Db3 Gb3 Ab3 Bb3 pada violoncello bergerak sebagai filler yang mengisi bagian sisa melodi utama atau titik mati (dead spot) dalam nada Bb5 pada violin I yang terjadi dari birama 4 sampai birama 5 .

\section{Lead In}

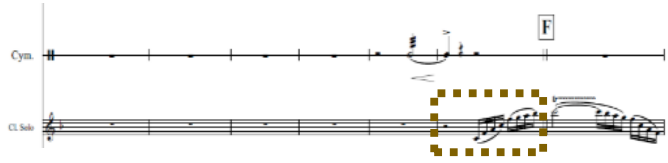

Notasi 2. Lead in pada bagian variasi V

Dari notasi 2 diatas, dapat dilihat pada kotak bergaris coklat merupakan lead in yang terdapat pada birama 65 bagian variasi $\mathrm{V}$ yang dimainkan oleh melodi utama yaitu clarinet solo in Bb. Lead in ini termasuk dalam bagian variasi $\mathrm{V}$ karena meskipun letaknya terdapat pada bagian variasi IV namun sesuai dengan fungsinya menurut kawakami lead in ini digunakan sebelum frase untuk mengenalkan melodi utamanya, maka melodi yang terbentuk pada ketukan ketiga dan keempat birama 65 digunakan sebagai awalan untuk mengenalkan melodi utama untuk bagian variasi $\mathrm{V}$.

Konstruksi lead in ini pada ketukan ketiga birama 65 menggunakan arpeggio akor $\mathrm{F}$ major (dalam tangga nada $\mathrm{Eb}$ major sama dengan akor $\mathrm{Eb}$ major) yaitu nada C4 F4 A4 C5. Kemudian pada ketukan keempat birama 65 konstruksi nada yang digunakan adalah konstruksi tangga nada yang dimulai dari nada F5 hingga nada C6 (maka terbentuk susunan nada F5 G5 A5 Bb5 C6). Hal tersebut sesuai dengan bentuk umum konstruksi lead in yaitu konstruksi tangga nada.

\section{Counter melody}

Counter melody mendukung melodi dan memainkan peran penting dalam mengaransemen, dan dapat digunakan dalam berbagai cara. Fungsi utamanya adalah untuk memperkuat perasaan harmoni dengan menggunakan garis melodi kedua, tetapi juga dapat digunakan untuk memberikan sentuhan aransemen individualitas melalui penyisipan frase yang efektif (Kawakami, 1975: 46). Maka fungsi counter melody adalah 
memperkuat perasaan harmoni. Berikut ini contoh counter melody pada bagian introduction.

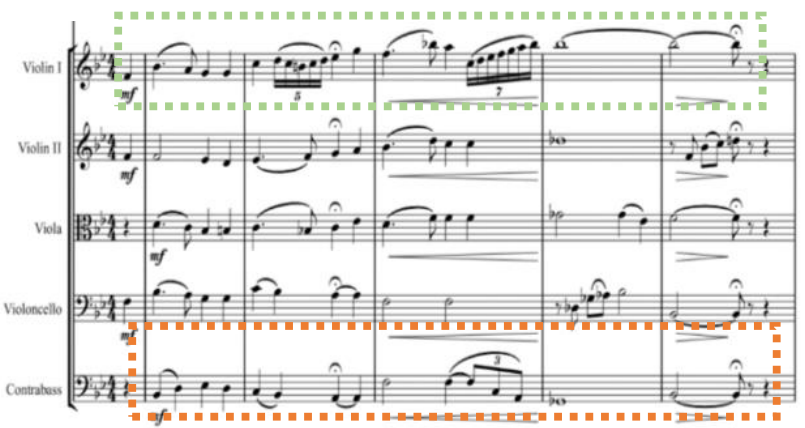

Notasi 3. Counter Melody pada bagian introduction

Notasi 3 diatas menunjukkan counter melody yang terdapat pada birama 1-5. Kotak dengan garis berwarna hijau merupakan melodi utama sedangkan kotak dengan garis berwarna orange merupakan bagian counter melody. Sesuai dengan fungsinya yaitu untuk memperkuat rasa harmoni melalui garis melodi kedua, contrabass memainkan garis melodi kedua yang sekaligus menjadi penguat rasa harmoni yang kemudian juga menjadi basis dalam membentuk obbligato.

\section{Cliché}

Cliche adalah teknik harmoni yang mewarnai chord yang sama dengan mengubah satu nada dari susunan chord tanpa mengubah fungsi dasar. Dengan menghubungkan nada karakteristik dari chord kemudian masing-masing diubah. Berikut ini adalah contoh cliché dalam aransemen lagu "Tanah Airku" karya Ibu Sud oleh Joko Suprayitno yang terdapat pada bagian introduction.

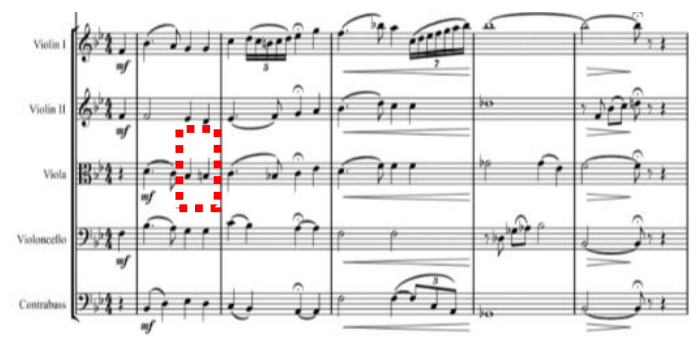

Notasi 4. Cliché pada bagian introduction

Pada notasi 4 kotak berwarna merah merupakan cliché. Karena pengertiannya adalah mewarnai akor yang sama dengan mengubah datu susunan akor tanpa mengubah fungsi dasarnya, maka nada $\mathrm{Bb}$ yang kemudian berganti dengan nada $\mathrm{B}$ bergerak selama akor Eb major. Akor Eb major yang memiliki susunan akor $\mathrm{Eb} \mathrm{G} \mathrm{Bb}$, diwarnai dengan hadirnya nada $\mathrm{B}$ setelah nada $\mathrm{Bb}$ di ketukan ketiga birama 1, sehingga terjadilah cliché.

\section{Filler like obbligato}

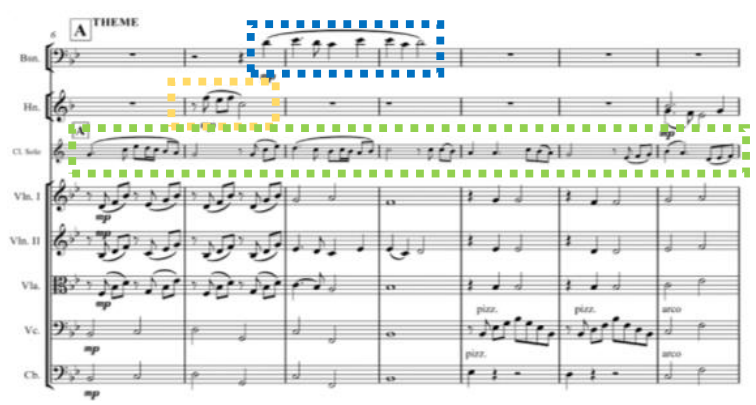

Notasi 5. Filler like obbligato pada bagian theme

Notasi 5 diatas menunjukkan filler like obbligato yang terdapat pada bagian theme birama 7-9 dengan dimulai dari adanya filler pada ketukan pertama birama 7 yang diawali dengan rest 1/2 ketukan. Kemudian obbligato pada 1 ketukan di akhir birama 7 hingga birama 9 .

Kotak dengan garis berwarna hijau merupakan melodi utama, kotak berwarna biru merupakan obbligato sedangkan kotak dengan garis berwarna kuning merupakan filler. Dilihat dari pengertiannya menurut kawakami dimana filler like obbligato yaitu ketika filler bergerak selama bagian sisa melodi utama, kemudian obbligato terbentuk, maka kontras antara motif vs rest dan rest vs motif. Artinya obbligato terbentuk setelah munculnya filler, dengan begitu akan terlihat dengan jelas rest vs motif antara garis melodi utama dengan filler, dan motif vs rest antara obbligato dengan bagian sisa filler.

Sesuai dengan pengertian diatas, maka melodi yang nampak pada notasi 4.5 pada bassoon dan horn in F merupakan filler like obbligato. Hal ini dikarenakan filler yang mengisi bagian sisa (dead spot) melodi utama pada horn in $\mathrm{F}$ membentuk obbligato pada bassoon yang memainkan melodi pada bagian sisa filler.

\section{Obbligato}

Yang terakhir adalah obbligato. Obbligato terdapat pada birama 33-37 bagian variasi II yang dimainkan oleh clarinet in $\mathrm{Bb}$ yang kemudian dilanjutkan pada horn in F. Obbligato ini sebenarnya memainkan melodi asli dari lagu "Tanah Airku" karya Ibu Sud frase 3 dan 4 bagian B. Namun melodi ini bukan sebagai melodi utama karena dalam bentuk variasi, fokus utamanya adalah variasi yang terjadi dari tema lagu yang dimainkan oleh solois yang dalam kasus ini dimainkan oleh clarinet solo in $\mathrm{Bb}$. Obbligato yang kedua ini dapat dilihat pada notasi 4.6 . 


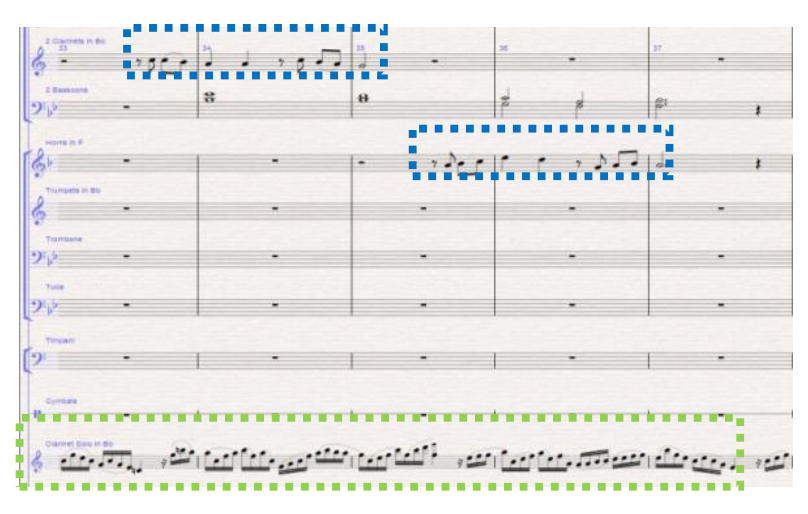

Notasi 6. Obbligato pada bagian variasi II

Kotak bergaris hijau pada notasi 4.6 menunjukkan melodi utama yang dimainkan oleh clarinet solo in $\mathrm{Bb}$ sedangkan kotak bergaris biru menunjukkan obbligato yang dimainkan oleh clarinet in $\mathrm{Bb}$ dan horn in $\mathrm{F}$. Seperti yang telah dijelaskan diatas bahwa clarinet in $\mathrm{Bb}$ dan horn in $\mathrm{F}$ sejatinya memainkan melodi asli lagu "Tanah Airku" karya Ibu Sud, namun dalam konteks ini melodi yang dimainkan oleh clarinet in $\mathrm{Bb}$ dan horn in $\mathrm{F}$ hanya merupakan melodi yang mendukung melodi utama yang dimainkan oleh clarinet solo in $\mathrm{Bb}$.

Hal ini dikarenakan fokus utamanya adalah clarinet solo in $\mathrm{Bb}$ yang sejatinya tengah memainkan variasi bentuk kedua dari tema lagu "Tanah Airku" karya Ibu Sud. Sesuai dengan fungsinya yang merupakan melodi sekunder yang berfungsi mendukung melodi utama yang dimainkan oleh clarinet solo in $\mathrm{Bb}$, maka melodi yang dimainkan oleh clarinet in $\mathrm{Bb}$ dan horn in $\mathrm{F}$ merupakan obbligato.

\section{Variasi Melodi pada Aransemen Lagu "Tanah Airku" Karya Ibu Sud oleh Joko Suprayitno}

Aransemen lagu "Tanah Airku" karya Ibu Sud oleh Joko Suprayitno memiliki bentuk musik variasi tema, sehingga terdapat satu solois (virtuoso) sebagai penyaji melodi utama yang akan divariasikan dalam beberapa bentuk. Dalam aransemen ini, bagian solo ini dibawakan oleh clarinet solo in $\mathrm{Bb}$.

Clarinet solo in $\mathrm{Bb}$ ini memainkan sebagian besar melodi utama lagu. Clarinet solo in $\mathrm{Bb}$ ini hanya tidak memainkan melodi utama pada bagian introduction, variasi IV, bridge pada variasi V dan Variasi VIII. Hal ini dikarenakan pada bagian tersebut memiliki fungsi-fungsi untuk menjembatani satu bentuk variasi dengan variasi yang lain.

Dalam melodi utama yang dimainkan oleh clarinet solo in $\mathrm{Bb}$, terjadi beberapa variasi yang dapat dilihat pada tabel 4.1. Pada tabel tersebut telah dipetakan pola irama dan variasi yang terjadi pada setiap bagian dalam aransemen lagu "Tanah Airku" karya Ibu Sud oleh Joko Suprayitno.

Tabel 1. Variasi pada melodi utama aransemen lagu "Tanah Airku" karya Ibu Sud oleh Joko Suprayitno

\begin{tabular}{|c|c|c|c|}
\hline $\begin{array}{ll}\text { Bagian } & \text { Nama } \\
\end{array}$ & $\begin{array}{r}\mathrm{N} \\
\text { ada Dasar }\end{array}$ & $\begin{array}{ll}\text { irama } & \text { Pola } \\
\end{array}$ & $\begin{array}{ll}\text { Jenis } \\
\text { Variasi }\end{array}$ \\
\hline ction $\quad$ Introdu & b major & \begin{tabular}{lr} 
& \multicolumn{2}{c}{ Diam } \\
bil dari dua \\
frase & terakhir \\
lagu & "Tanah \\
Airku & \\
\end{tabular} & $\begin{array}{l}\text { Melo } \\
\text { dic variation } \\
\text { and fake via } \\
\text { non-chordal }\end{array}$ \\
\hline Theme & b major & $\begin{array}{ll} & \text { Tema } \\
\text { lagu } & \text { "Tanah } \\
\text { Airku" } & \\
\end{array}$ & $\begin{array}{r}\text { Tida } \\
\mathrm{k} \text { ada variasi }\end{array}$ \\
\hline Variasi & b major & $\begin{array}{ll} & \text { Pola } \\
\text { triplet } & \end{array}$ & $\begin{array}{l}\text { Melo } \\
\text { dic variation } \\
\text { and fake via } \\
\text { non-chordal } \\
\text { dan tail }\end{array}$ \\
\hline Variasi & b major & not $1 / 16^{\text {Pola }}$ & $\begin{array}{l}\text { Melo } \\
\text { dic variation } \\
\text { and fake via } \\
\text { non-chordal }\end{array}$ \\
\hline Variasi & b major & $\begin{array}{l}\text { Komb } \\
\text { inasi triplet dan } \\
\text { not } 1 / 16\end{array}$ & $\begin{array}{l}\text { Melo } \\
\text { dic variation } \\
\text { and fake via } \\
\text { non-chordal } \\
\text { dan tail }\end{array}$ \\
\hline Variasi & b major & $\begin{array}{ll} & \text { Tema } \\
\text { lagu } & \text { "Tanah } \\
\text { Airku" } & \\
\end{array}$ & $\begin{array}{r}\text { Tida } \\
\mathrm{k} \text { ada variasi }\end{array}$ \\
\hline $\mathrm{V}+$ bridge & b major & $\begin{array}{l}\text { Komb } \\
\text { inasi triplet dan } \\
\text { not } 1 / 16+\text { frase } \\
\text { pertama lagu } \\
\text { "Tanah Airku" } \\
\text { diulang } 3 \text { kali }\end{array}$ & $\begin{array}{l}\text { Melo } \\
\text { dic variation } \\
\text { and fake via } \\
\text { non-chordal, } \\
\text { tail dan } \\
\text { ornament }\end{array}$ \\
\hline Variasi & minor $\mathrm{C}$ & $\begin{array}{lr} & \text { Tema } \\
\text { lagu } & \text { "Tanah } \\
\text { Airku" } & \text { dalam } \\
\text { tangga } & \text { nada } \\
\text { minor } & \\
\end{array}$ & $\begin{array}{l}\text { Melo } \\
\text { dic variation } \\
\text { and fake via } \\
\text { non-chordal }\end{array}$ \\
\hline Variasi & minor $\mathrm{C}$ & $\begin{array}{r}\text { Komb } \\
\text { inasi not } 1 / 32\end{array}$ & $\begin{array}{l}\text { Melo } \\
\text { dic variation } \\
\text { and fake via } \\
\text { non-chordal }\end{array}$ \\
\hline Cadenz & - & $\begin{array}{l}\text { Sesuai } \\
\text { kehendak } \\
\text { solois }\end{array}$ & - \\
\hline Finale & major $F$ & 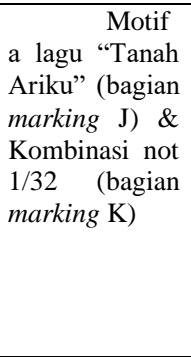 & $\begin{array}{l}\text { Sequ } \\
\text { ence on } \\
\text { interval } \\
\text { (bagian } \\
\text { marking } \mathrm{J} \text { ) \& } \\
\text { Melodic } \\
\text { variation and } \\
\text { fake via non- } \\
\text { chordal } \\
\text { (bagian } \\
\text { marking } \mathrm{K} \text { ) }\end{array}$ \\
\hline
\end{tabular}

Pada table 1 dapat dilihat perubahan yang dilakukan pada tiap bagian dari sisi pola irama dan juga nada dasarnya. Perubahan pola irama hampir di setiap bagian ini sekilas memang mengarah pada terjadinya rhytmyc variation and fake. Pengertian rhytmyc variation and fake yang menurut Kawakami (1975: 20) merupakan perubahan melodi 
dengan memindahkan posisi irama tanpa mengganggu garis melodi asli. Dilihat dari pengertian tersebut maka penggunaan rhytmyc variation and fake dilakukan dengan menggeser posisi nada dalam pola irama sehingga terjadi syncopation dan anticipation.

Dalam aransemen lagu "Tanah Airku" karya Ibu Sud oleh Joko Suprayitno ini, melodi utama yang ditampilkan pada setiap bagian tidak hanya divariasikan dengan menggeser posisi nada dalam pola irama namun beberapa dengan mengubah pola irama seutuhnya menjadi pola triplet (seperti pada bagian variasi I) atau bisa juga dengan kombinasi not $1 / 16$ dengan triplet not $1 / 32$ (seperti pada bagian variasi III).

Dalam perubahan pola irama yang terjadi beberapa kali tersebut, terdapat juga beberapa nada yang disisipkan dalam melodi asli lagu "Tanah Airku" karya Ibu Sud. Sisipan nada yang dimasukkan kedalam melodi asli lagu "Tanah Airku" karya Ibu Sud tersebut juga tidak hanya berasal dari akor yang berjalan pada melodi tersebut, namun juga dari nada-nada diluar akor.

Dilihat dari penjelasan diatas maka variasi yang terjadi pada melodi utama aransemen lagu "Tanah Airku" karya Ibu Sud oleh Joko Suprayitno ini merupakan jenis melodic variation and fake via non-chordal. Melodic variation and fake via nonchordal ini memiliki basis seperti halnya melodic variation and fake hanya saja nada yang disisipkan guna memvariasikan melodi utama tidak hanya menggunakan nada dalam akor namun dapat juga diambil dari nada diluar akor.

Meskipun begitu, tidak hanya melodic variation and fake via non-chordal saja yang digunakan Joko Suprayitno dalam memvariasikan tema lagu "Tanah Airku" karya Ibu Sud. Beberapa variasi seperti ornament, tail dan juga sequence on interval juga ikut mewarnai melodi utama aransemen lagu "Tanah Airku" karya Ibu Sud oleh Joko Suprayitno seperti yang tampak pada tabel 4.1.

Contoh variasi yang terjadi pada melodi utama aransemen lagu "Tanah Airku" karya Ibu Sud oleh Joko Suprayitno dapat dilihat pada notasi dibawah ini. Namun seperti pada tabel 4.1, bagian theme, variasi IV dan cadence dikecualikan karena tidak terdapat variasi yang signifikan dalam melodi utama. Pada bagian theme melodi utama dibawakan tanpa variasi, pada bagian variasi IV melodi utama dibawakan seperti melodi asli hanya saja nada dasarnya diubah, sedangkan bagian cadence merupakan bagian solo dimana solois membentuk melodi sesuai dengan kemauannya sehingga sangatlah bebas.

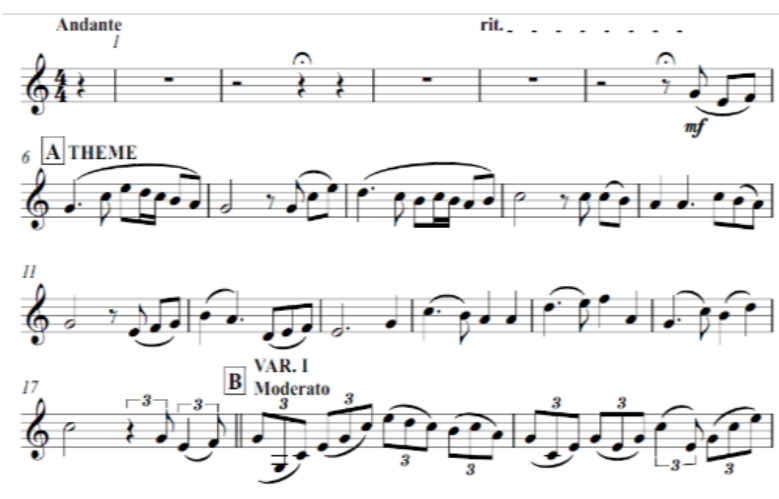

Notasi 7. Melodi utama pada bagian theme

Notasi 7 merupakan melodi utama pada bagian theme dimana pada bagian ini melodi utama yang dimainkan oleh clarinet solo in Bb memainkan melodi asli lagu "Tanah Airku" karya Ibu Sud tanpa variasi. Pada notasi 4.7 terdapat melodi utama pada bagian theme. Melodi utama pada bagian theme dimulai dari okmat $1 \frac{1}{2} 2$ ketukan pada birama 5 yang kemudian diakhiri pada birama 17 ketukan 2. Notasi 4.28 digunakan untuk pembanding dengan melodi yang telah divariasi pada bagian yang lain.

\section{Variasi Melodi pada bagian Introduction}

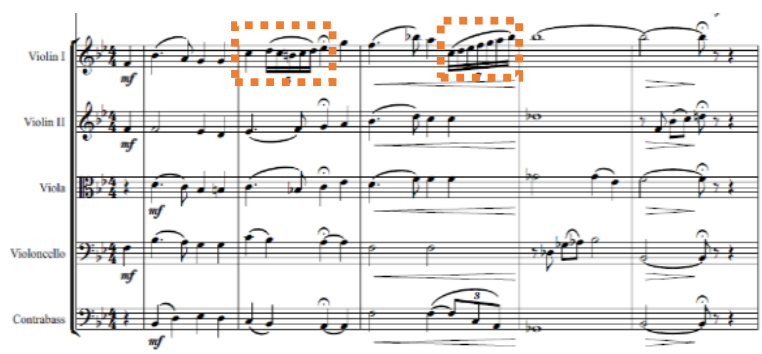

Notasi 8. Melodic variation and fake via non-chordal pada bagian Introduction

Pada notasi 4.8 dapat dilihat variasi yang terjadi pada melodi utama yang dimainkan oleh violin I pada bagian introduction. Bagian introduction ini memainkan bagian $\mathrm{C}$ lagu "Tanah Airku" karya Ibu Sud. Kotak bergaris orange merupakan melodic variation and fake via nonchordal. Terdapat dua melodic variation and fake via non-chordal, yang pertama pada birama 2 ketukan kedua dan birama 3 ketukan keempat.

Dilihat dari pengertiannya dimana melodic variation and fake via non-chordal memiliki basis dari melodic variation and fake dimana melodi asli lagu diubah dengan menyisipkan nada dalam akor, hanya saja melodic variation and fake via nonchordal dapat lebih leluasa karena dapat menyisipkan tidak hanya nada dalam akor saja 
namun nada diluar akor juga dapat disisipkan kedalam melodi asli lagu.

Dari pengertian diatas maka melodi dalam kotak bergaris orange merupakan melodic variation and fake via non-chordal karena pada kotak yang pertama pada birama 2 ketukan kedua, nada D C B C D quintuplet tersebut bergerak pada akor Dm namun terdapat nada $\mathrm{C}$ dan $\mathrm{B}$ yang bukan merupakan nada pembentuk akor Dm. Selanjutnya pada birama 3 ketukan keempat juga terdapat septuplet dengan nada C D Eb F G A Bb yang mengisi akor $\mathrm{F}$ major.

Beberapa nada dalam rangkaian nada tersebut seperti nada $\mathrm{D}, \mathrm{Eb}, \mathrm{G}$, dan Bb bukan merupakan nada pembentuk akor F major. Sehingga variasi yang terjadi pada melodi utama bagian introduction ini adalah melodic variation and fake via nonchordal. Hal ini dikarenakan melodi yang diubah disisipi tidak hanya dengan nada dalam akor melainkan nada diluar akor juga.

Variasi melodi pada bagian Variasi I

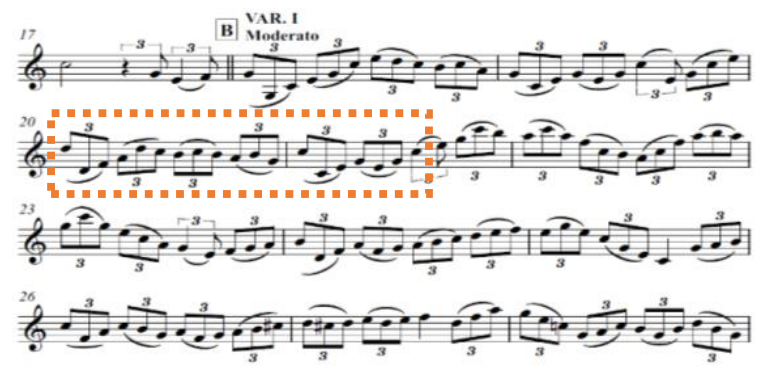

Notasi 9. Melodic variation and fake via nonchordal pada bagian variasi I

Kemudian variasi pada melodi utama bagian variasi I dapat dilihat pada notasi 4.9. Kotak bergaris orange merupakan melodic variation and fake via non-chordal. Contoh pada variasi I yang menunjukkan bahwa terdapat melodic variation and fake via non-chordal salah satunya adalah pada frase kedua.

Pola irama yang memiliki basis not triplet ini tidak hanya merubah pola irama seutuhnya menjadi bentuk triplet namun juga menyisipkan beberapa nada dengan nada dalam akor maupun nada diluar akor. Dapat dilihat pada notasi 4.9 dalam kotak bergaris orange birama 20 ketukan ketiga, yaitu terdapat rangkaian nada B C B (yang dalam tangga nada $\mathrm{Bb}$ major sama dengan nada A Bb A). Nada C pada rangkaian tersebut merupakan nada sisipan yang digunakan sebagai variasi. Namun nada C pada rangkaian nada tersebut merupakan nada sisipan yang berasal dari luar akor karena akor yang tengah berjalan adalah akor $\mathrm{G}$ major (yang dalam tangga nada $\mathrm{Bb}$ sama dengan $\mathrm{F}$ major) yang memiliki konstruksi nada G B D.
Dalam hal ini nada $\mathrm{C}$ ini adalah nada diluar akor yang disisipkan dalam melodi sebagai variasi untuk melodi utama. Karena alasan ini maka pada bagian variasi I, melodi utama divariasikan dengan melodic variation and fake via non-chordal. Kemudian juga terdapat variasi tail. Tail ini dapat dilihat pada notasi 4.10 .

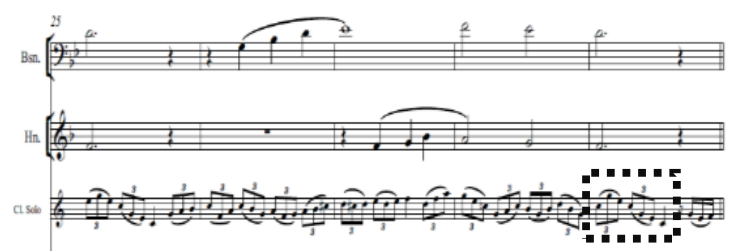

Notasi 11. Tail pada bagian variasi I

Dari notasi 4.11 diatas, dapat dilihat pada kotak bergaris hitam merupakan tail yang terdapat pada birama 29 bagian variasi I yang dimainkan oleh melodi utama yaitu clarinet solo in $\mathrm{Bb}$. Akhir melodi utama yang seharusnya nada $\mathrm{C}$ (dalam tangga nada $\mathrm{Bb}$ sama dengan nada $\mathrm{Bb}) 3$ ketukan diubah menjadi akhiran dengan arpeggio akor $\mathrm{C}$ major (dalam tangga nada $\mathrm{Bb}$ sama dengan akor $\mathrm{Bb}$ major) yaitu nada C5 G5 E5 C5 G4 E4 C4. Tail yang pertama tersebut digunakan sebagai penutup bagian variasi I.

\section{Variasi Melodi pada bagian Variasi II}

Sama halnya dengan bagian variasi I, bagian variasi II juga memiliki melodi utama yang telah divariasi dengan melodic variation and fake via non-chordal. Hal ini dapat dilihat pada notasi 4.12 dimana kotak bergaris orange pada birama 32 tersebut merupakan contoh melodic variation and fake via non-chordal pada bagian variasi II.

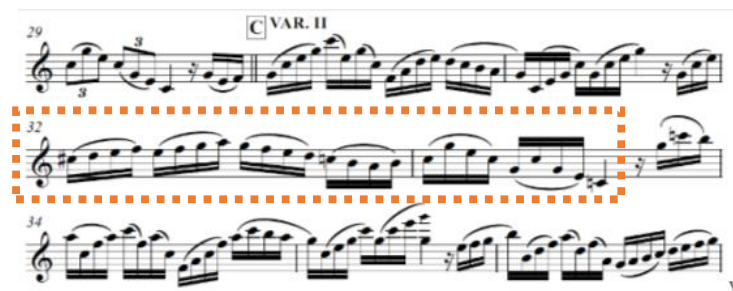

Notasi 12. Melodic variation and fake via non-chordal pada bagian variasi II

Melodic variation and fake via non-chordal ini dapat dilihat pada ketukan pertama birama 32 dimana terdapat rangkaian nada C\# D E F (dalam tangga nada Bb sama dengan B C D Eb). Rangkaian nada tersebut bergerak pada akor Dm (yang dalam tangga nada $\mathrm{Bb}$ sama dengan akor $\mathrm{Cm}$ ). dilihat dari konstruksi nada dari akor Dm yaitu D F A, tidak terdapat nada $\mathrm{C} \#$ dan $\mathrm{E}$. Hal ini menunjukkan bahwa nada $\mathrm{C \#}$ dan $\mathrm{E}$ sengaja disisipkan pada 
melodi utama untuk membentuk konstruksi jenis tangga nada D minor harmonik yaitu C\# D E F. Sisipan nada C\# dan E ini juga membuktikan variasi yang digunakan pada melodi utama bagian variasi II ini adalah melodic variation and fake via nonchordal.

\section{Variasi Melodi pada bagian Variasi III}

Masih dengan variasi yang sama, melodi utama bagian variasi III juga divariasikan dengan menggunakan melodic variation and fake via nonchordal. Contoh melodic variation and fake via non-chordal pada bagian variasi III ini dapat dilihat pada notasi 4.13 dengan penanda kotak bergaris orange.

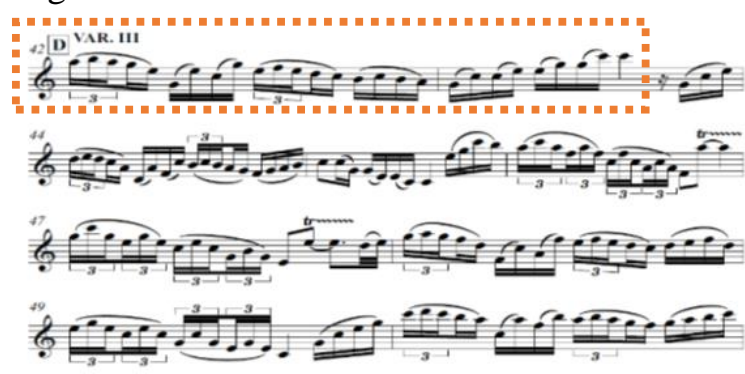

Notasi 13. Melodic variation and fake via nonchordal pada bagian variasi III

Melodic variation and fake via non-chordal pada melodi utama bagian III ini dapat dilihat pada birama 42 ketukan pertama. Rangkaian nada dengan pola irama kombinasi not 1/16 dan triplet not 1/32 memiliki nada A B A G E (yang dalam tangga nada Bb major sama dengan G A G F D). Rangkaian nada tersebut berjalan pada akor $\mathrm{C}$ major (yang dalam tangga nada $\mathrm{Bb}$ major sama dengan $\mathrm{Bb}$ major) yang memiliki nada pembentuk akor yaitu $\mathrm{CE} \mathrm{G}$, namun dalam rangkaian nada tersebut nada $\mathrm{A} B \mathrm{~A}$ bukan merupakan nada pembentuk akor $\mathrm{C}$ major.

Rangkaian nada tersebut juga terasa seperti gerak suspensi karena pada nada $G$ yang seharusnya pada melodi asli berada tepat pada ketukan pertama mundur $1 / 2$ ketukan dibelakang triplet not 1/32 dengan nada A B A. Ini menunjukkan terjadinya melodic variation and fake, dan dengan alasan bahwa nada A B A bukan merupakan bagian dari akor $\mathrm{C}$ major, maka pada bagian variasi III ini, melodi utama divariasi dengan melodic variation and fake via non-chordal.

Selanjutnya terdapat tail pada bagian variasi III ini. Berikut ini tail pada bagian variasi III.

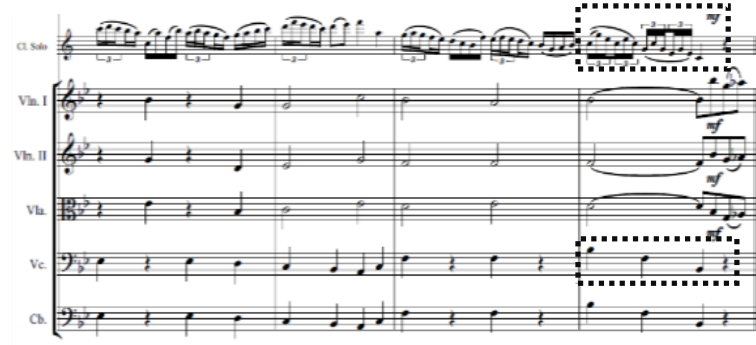

Notasi 14. Tail pada bagian variasi III

Pada notasi 4.14 nampak tail yang terdapat pada birama 53 bagian variasi III yang dimainkan oleh melodi utama yaitu clarinet solo in Bb. Dalam tail 3 ini terdapat dua tail yaitu yang terdapat pada melodi utama dan juga pada violoncello yang kemudian di-double dengan contrabass. Motif yang diberikan untuk tail pada melodi utama masih menggunakan arpeggio akor $\mathrm{C}$ major (dalam tangga nada $\mathrm{Bb}$ sama dengan akor $\mathrm{Bb}$ major) dengan ritme triplet 1/16, sehingga terbentuk susunan nada C5 G5 E5 C5 E5 C5 G4 C5 G4 E4 G4 E4 C4.

Selaras dengan tail pada melodi utama, tail yang terjadi pada violoncello dan contrabass juga merupakan arpeggio akor $\mathrm{C}$ major (dalam tangga nada $\mathrm{Bb}$ sama dengan akor $\mathrm{Bb}$ major) namun dengan not 1/8 sehingga nada Bb3 F3 Bb2 pada violoncello nampak memberi penegasan harmoni yang lebih efektif dalam akhir bagian III.

Variasi Melodi pada bagian Variasi V

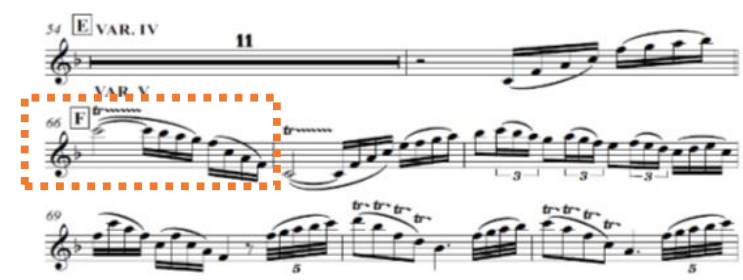

Notasi 15. Melodic variation and fake via non-chordal dan ornament pada bagian variasi $\mathrm{V}$

Kemudian pada bagian variasi $\mathrm{V}+$ bridge terdapat melodic variation and fake via nonchordal, tail dan juga ornament. Kotak bergaris orange pada notasi 4.15 diatas menunjukkan terjadinya melodic variation and fake via nonchordal dan juga pemberian ornament. Hal ini dapat dilihat pada birama 66 ketukan ketiga dimana terdapat nada $\mathrm{C}$ Bb A G. Nada $\mathrm{C}$ dalam rangkaian nada tersebut sebenarnya merupakan sisa panjang nada dari nada $\mathrm{C}$ yang sudah bergerak sejak ketukan pertama birama 66.

Rangkaian nada tersebut berjalan pada akor $\mathrm{G}$ minor (yang dalam tangga nada Eb major sama dengan $\mathrm{F}$ minor) yang memiliki nada penyusun yaitu $G$ Bb $D$. Nada $C$ pada awal rangkaian nada 
tersebut masuk dalam sisa panjang nada $\mathrm{C}$ pada ketukan pertama maka tidak dihitung sebagai nada yang berdiri sendiri. Sedangkan nada A pada rangkaian nada tersebut bukan merupakan nada penyusun akor $\mathrm{G}$ minor. Sehingga dapat disimpulkan bahwa pada melodi utama bagian variasi $\mathrm{V}$ divariasikan dengan melodic variation and fake via non-chordal.

Selain melodic variation and fake via nonchordal, terdapat juga ornament yang diberikan pada melodi utama dimana dapat dilihat dalam kotak bergaris orange pada notasi 4.15 terdapat penambahan ornament trill yang sengaja dimasukkan dalam melodi utama variasi $\mathrm{V}$ untuk memberikan warna yang lebih banyak dalam melodi. Yang terakhir terdapat tail pada akhir melodi utama pada bagian variasi $\mathrm{V}$ ini. Berikut ini tail yang terjadi pada bagian variasi $\mathrm{V}$.

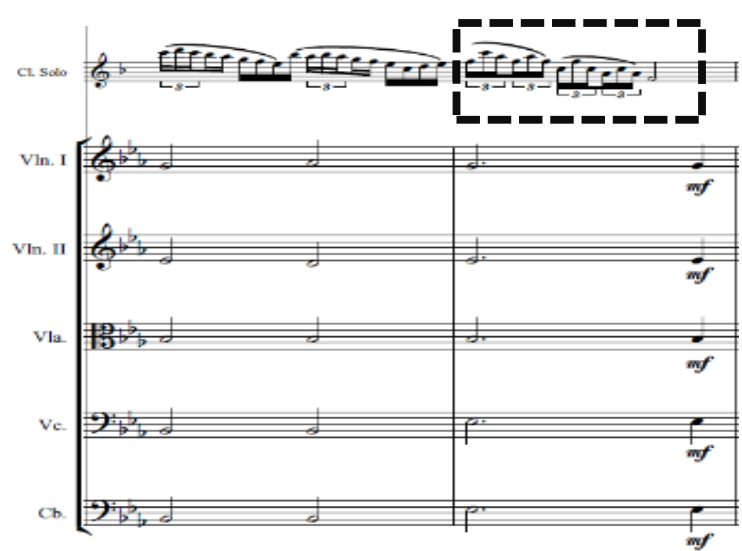

Notasi 16. Tail pada bagian variasi V

Notasi 4.16 menunjukkan tail yang terdapat pada akhir melodi utama bagian variasi $\mathrm{V}$. Sebenarnya tail ini tidak terjadi pada akhir bagian variasi $\mathrm{V}$ karena pada akhir bagian variasi $\mathrm{V}$ masih terdapat bagian bridge yang menghubungkan variasi V dan variasi VI. Namun karena pemisahan bagian antara variasi $\mathrm{V}$ dan bridge, maka melodi yang dimainkan clarinet solo in Bb sebagai melodi utama pada birama 77 merupakan tail dari bagian variasi $\mathrm{V}$.

Tail yang keempat ini juga menggunakan arpeggio untuk menghias akhir melodi utama yang seharusnya hanya nada panjang 3 ketukan pada ketukan pertama sampai ketukan ketiga. Arpeggio akor $\mathrm{F}$ major (yang dalam tangga nada $\mathrm{Eb}$ sama dengan Eb major) digunakan dalam not triplet 1/16 dengan susunan nada F5 C6 A5 F5 A5 F5 C5 F5 C5 A4 C5 A4 F4. Tail yang keempat ini menutup melodi utama pada akhir bagian variasi $\mathrm{V}$ sebelum masuk bridge.

\section{Variasi Melodi pada bagian Variasi VI}

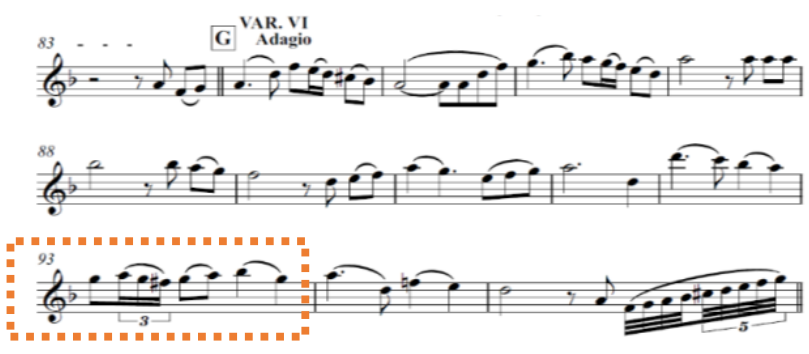

Notasi 17. Melodic variation and fake via nonchordal pada bagian variasi VI

Setelah penjelasan mengenai variasi melodi pada bagian introduction, variasi I, variasi II, variasi III, dan variasi V, selanjutnya adalah variasi melodi pada bagian variasi VI. Variasi yang terjadi pada variasi VI dapat dilihat pada notasi 4.17. Pada notasi 4.17, dapat dilihat bahwa pada bagian variasi VI menggunakan jenis variasi melodic variation and fake via non-chordal.

Dapat dilihat pada kotak bergaris orange dimana terjadi pada ketukan pertama birama 93. Rangkaian nada G A G F\# yang berjalan pada akor $\mathrm{G}$ minor (yang dalam tangga nada Eb sama halnya dengan akor $\mathrm{F}$ minor). Karena nada $\mathrm{A}$ dan F\# pada rangkaian nada tersebut bukan merupakan nada penyusun akor $\mathrm{G}$ minor maka melodi yang divariasi ini disisipi tidak hanya dengan nada dalam akor namun juga disisipi dengan nada-nada diluar akor. Artinya melodi utama pada bagian variasi VI ini divariasi dengan melodic variation and fake via non-chordal.

\section{Variasi Melodi pada bagian Variasi VII}

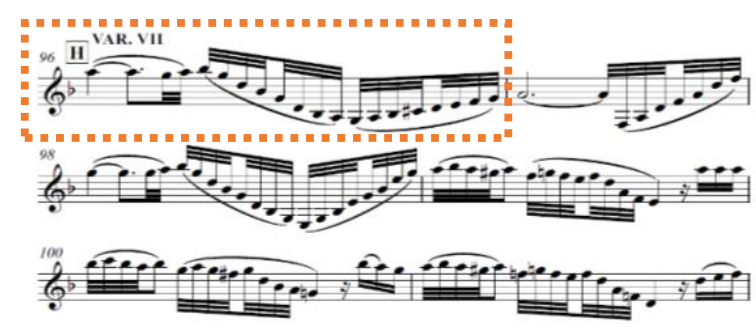

Notasi 18. Melodic variation and fake via non-chordal pada bagian variasi VII

Pada bagian variasi VII, melodi utama juga divariasikan dengan melodic variation and fake via non-chordal. Hal ini dapat dilihat pada notasi 4.18 dimana ditandai dengan kotak bergaris orange. Rangkaian nada pada ketukan keempat birama 96 dengan ritme not 1/32 menunjukkan pola konstruksi melodi jenis tangga nada.

Pola semacam ini menggunakan urutan nada dalam tangga nada sebagai pergerakan melodinya. Pada ketukan keempat birama 96 tersebut terdapat rangkaian nada G A Bb C\# D E F G (yang dalam 
tangga nada Eb sama dengan F G Ab Bb C D Eb F). Rangkaian nada tersebut bergerak pada akor E halfdim7 (yang pada tangga nada Eb sama dengan D halfdim7) yang memiliki nada penyusun yaitu $\mathrm{E}$ $\mathrm{GBb}$ D.

Dalam rangkaian nada tersebut terdapat nada A C\# F yang bukan merupakan bagian dari nada penyusun akor E halfdim7. Sehingga dapat disimpulkan bahwa melodi utama pada bagian variasi VII ini menggunakan melodic variation and fake via non-chordal. Bagian terakhir yang akan dibahas yaitu bagian finale dimana variasi melodi yang digunakan pada bagian ini adalah sekuensi dan juga melodic variation and fake via non-chordal.

\section{Variasi Melodi pada bagian Finale}

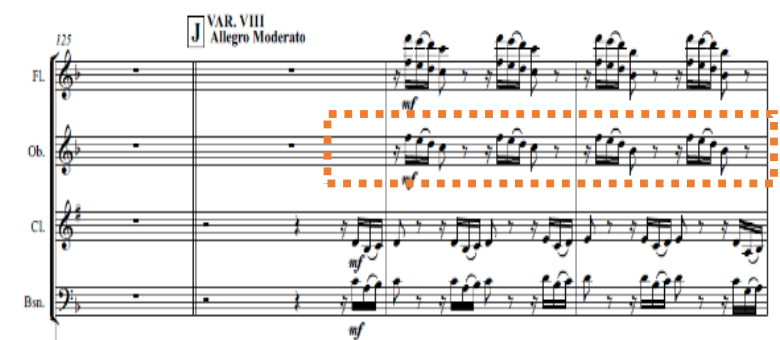

Notasi 19. Sekuensi pada bagian finale

Pada notasi 4.19 nampak variasi yang pertama pada bagian ini yaitu sekuensi. Pada dasarnya sekuensi yang berarti pengulangan pada tingkat nada yang berbeda. Dapat dilihat pada kotak bergaris orange pada notasi 4.19 dimana clarinet in $\mathrm{Bb}$ memainkan not 1/16 dengan motif dasar yang digunakan adalah motif a bagian A lagu "Tanah Airku" karya Ibu Sud.

Nada D B C D (yang dalam tangga nada F major sama dengan $\mathrm{C} \mathrm{A} \mathrm{Bb} \mathrm{C)} \mathrm{pada} \mathrm{ketukan}$ keempat birama 126 yang diulang sama persis pada ketukan kedua birama 127 kemudian kedua motif tersebut diulang pada satu tingkat lebih tinggi menjadi E C D E (yang dalam tangga nada F major sama dengan $\mathrm{D}$ Bb C D) pada ketukan keempat birama 127 dan ketukan kedua birama 128. Hal ini membuktikan telah terjadi sekuensi naik pada motif dasar yang digunakan pada bagian finale ini.

Kemudian melodic variation and fake via non-chordal yang terdapat pada bagian finale dapat dilihat pada notasi 4.20

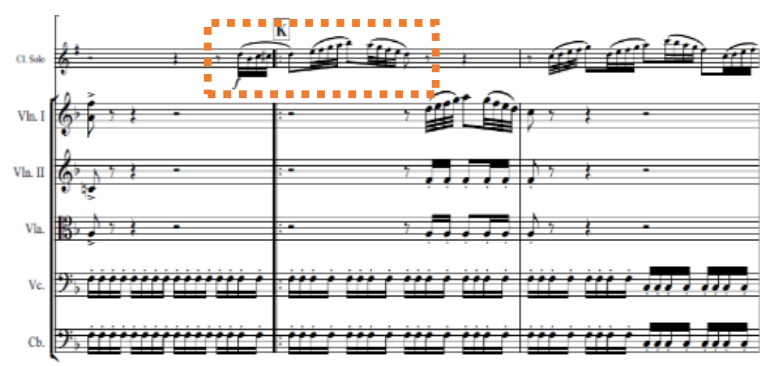

Notasi 20. Melodic variation and fake via nonchordal pada bagian finale

Pada notasi 4.20 dapat dilihat melodi utama yang dimainkan oleh clarinet solo in $\mathrm{Bb}$ memainkan sebuah frase dengan dasar frase pertama lagu "Tanah Airku" karya Ibu Sud. Diawal frase ini yaitu pada ketukan keempat birama 134 nada yang dimainkan oleh clarinet solo in $\mathrm{Bb}$, nada yang dimainkan adalah D B C C\# D. Rangkaian nada ini merupakan bentuk variasi dari motif a bagian A lagu "Tanah Airku" karya Ibu Sud.

Nada C\# pada variasi motif tersebut merupakan passing tone antara nada $\mathrm{C}$ dan $\mathrm{D}$. Nada $\mathrm{C} \#$ ini juga menjadi nada sisipan yang diambil bukan dari akor yang berjalan. Karena akor yang tengah berjalan pada awal bagian ini adalah akor $\mathrm{G}$ major (yang dalam tangga nada $\mathrm{F}$ major sama dengan akor $\mathrm{F}$ major), maka nada $\mathrm{C \#}$ merupakan nada diluar akor yang disisipkan pada motif lagu di melodi utama ini. Sehingga jelas terjadi melodic variation and fake via non-chordal yang terjadi pada bagian finale ini.

\section{PENUTUP}

Lagu "Tanah Airku" karya Ibu Sud terdiri dari 3 frase dimana setiap frase terdiri dari 2 motif. Dari struktur lagu "Tanah Airku" karya Ibu Sud tersebut dibuatlah aransemen lagu "Tanah Airku" karya Ibu Sud oleh Joko Suprayitno. Aransemen lagu "Tanah Airku" karya Ibu Sud oleh Joko Suprayitno memiliki bentuk variasi tema dimana didalamnya terdapat 12 variasi diantaranya, introduction, theme, variasi I, variasi II, variasi III, variasi IV, variasi V + bridge, variasi VI, variasi VII, cadenza, variasi VIII, dan finale.

Dalam aransemen lagu "Tanah Airku” karya Ibu Sud oleh Joko Suprayitno melodi utama yang mempunyai peran penting divariasi dengan menggunakan melodic variation and fake via nonchordal dan sekuensi. Namun variasi yang dominan digunakan dalam memvariasikan tema lagu "Tanah Airku" karya Ibu Sud adalah melodic variation and fake via non-chordal. Variasi ini terdapat hampir pada setiap bagian, kecuali bagian theme, variasi IV dan cadenza. Selain pada melodi utama terdapat pula 
beberapa variasi melodi yang digunakan dalam menghias aransemen ini diantaranya, filler (melodic filler, tail, dan lead in), counter melody, cliché, obbligato, dan yang terakhir filler like obbligato.

\section{DAFTAR PUSTAKA}

Banoe, Pono. 2003. Kamus Musik: Yogyakarta: Kanisius

Departemen Pendidikan Nasional. 1989. Kamus Besar Bahasa Indonesia. Jakarta: Balai Pustaka.

Kawakami, Genichi. 1975. Arranging Popular Music. Tokyo: Yamaha Music Foundation.

Kostka, Stefan \& Dorothy Payne. 1995. Tonal Harmony with an introduction to Twentieth-Century Music. Edisi Ketiga. United State of America: McGraw-Hill, Inc.

Moleong, Lexy J. 1990. Metode Penelitian Kualitatif. Bandung: PT Remaja Rosdakarya.

Narselina, P. M. (2015). Analisis Bentuk Musikal dan Struktur Lagu Tanah Airku Karya Ibu Soed Aransemen Joko Suprayitno untuk Duet Vokal dan Orkestra (Doctoral dissertation, Institut Seni Indonesia Yogyakarta).

Prier, Karl-Edmund. 2004. Ilmu Bentuk Musik. Yogyakarta: Pusat Musik Liturgi

Prier, Karl-Edmund. 2014. Kamus Musik. Yogyakarta: Pusat Musik Liturgi

Stein, Leon. Tanpa Tahun. Structure \& Style Expanded Edition, The Study and Analysis of Musical Forms

Sturbe, Gustav. Tanpa Tahun. The Theory And Use of Chords A Text-Book of Harmony. United State of America: Oliver Ditson Company

Sugiyono. 2014. Metode Penelitian Kuantitatif, Kualitatif, dan $R \& D$. Bandung: Penerbit Alfabeta.

Suwahyono, A. (2018). Caprice No. 24 Karya Paganini Pada Solo Gitar Aransemen John Williams (Analisis Bentuk Musik). Virtuoso (Jurnal Pengkajian dan Penciptaan Musik), 1(1), 24-29.

Syafiq, Muhammad. 2003. Ensiklopedia Musik Klasik: Yogyakarta: Adicita Karya Nusa.

Tim Penyusun. 2014. Panduan Penulisan dan Penilaian Skripsi. Surabaya. Unesa

Yudhiani P, F. A. R. I. D. A. (2016). Karya Musik "Moira" Dalam Tinjauan Variasi Melodi Dan Teknik Permainan Solo Viola. Solah, 6(2). 